\title{
Application of the King's Philosophy in the Professional Learning Community to Develop Classroom Learning Promotion Network in Schools in Kanchanaburi Province
}

\author{
Karanphon Wiwanthamomgkon \\ Ph.D. Faculty of Education, Kanchanaburi Rajabhat University Thailand \\ karanphon@gmail.com
}

\begin{abstract}
The purpose of this research was conducted by research and development using Participatory Action Research (PAR) which applied article was to the King's Philosophy in the professional learning community and the systematic thinking to develop classroom learning promotion network. The purposes of this research article were 1) to study the background of the school and the need of the network development, 2) to develop the model, 3) to study result of model utilization, 4) to evaluate and conduct the lessons learned. The target group of the study were from 31 teachers from 6 schools who attended the network development with volunteering. Results indicated that 1) all educational organization realize the important and need of network development, 2) results of the developed model that assessed by experts showed at good level $($ Mean $=3.82$, S.D $=0.67$ ). Process of networking operation with 3 steps consisted of step 1 is to build the network and set the target, step 2 is to cooperate creative network development, and step 3 is to conduct lessons learned and extend learning network. 3) Result of model utilization showed the cooperation of school directors, teachers, students, and CCF foundation, and it was shown 92.59 percent in collaborative action. 4) Results of evaluate and conduct the lessons learned showed that the use of networking to promote learning management was good level, self-development of teacher was at good level, development of classroom management of teachers was at good level, students showed good level after the development, students have shown learning behavior and knowledge at reasonable level
\end{abstract}

Index Terms

King's Philosophy, Professional Learning Community, Classroom Learning Network

Article Received: 10 August 2020, Revised: 25 October 2020, Accepted: 18 November 2020

\section{Introduction}

The development of the country for prosperity is something that all sectors must work together to drive prosperity according to each region, local area and context. The important changes affect Thailand according to the changing circumstances of the world in the $21^{\text {st }}$ century with a significant impact on the education sector of Thailand. The world has changed from the 20th century to the 21 st century has the essence of change consisted of: 1) the transition from the American century to the Asian century, 2) the transition from the era of wealth to the extreme, both nature, politics, business and human morality, 3) the beginning of the shift of power from the government to the people, from the trend of the aforementioned changes affect the educational significance of Thailand that making Thailand must have adjustment of the country's strategy to be up-todate and keep pace with the changing of the world in the current day. For the strategy in Thailand, the government has established four main strategies for responding to this change: strategy to build country competitiveness (Growth \& Competitiveness), strategy to create opportunities on equality and social equality (inclusive growth), strategy for growth on quality of life environment friendly (Green Growth), strategy for balancing and development public administration management system by giving weight to education. This is a challenge to practice in order to truly enhance the quality of education. (Office of the Education Council Secretariat, 2014) [1].

The process of thinking about modern education management need to modify the education management that gives the school an opportunity to develop and receive sustainable development. Professional learning communities are one way to strengthen the provision of education in each area. The practice of the professional learning community in action must be in the direction of professional practice, and the selection of royal science to apply in practice. It is one of the useful guidelines and in accordance with government policy, encourages and encourages all schools to apply the royal science of King Rama IX and X to apply to work in schools until producing good results and practicing using the King's Philosophy until it becomes a good habit. There are many dimensions for choosing to use royalism, and principles of work are one approach that can be applied well. There are 23 principles of work that His Majesty has bestowed upon the principles of practice that can be integrated and applied in every task as well as applying King's Philosophy, dimension, and work principles to the development of learning management together with community processes and professional learning. It is a principle that can be integrated into the professional learning community. Developing appropriate education in the context of Thai people can be flexible and applicable to all areas in all areas of education.

Education management in Sangkhlaburi District Kanchanaburi, it is a border area with many educational management agencies. Education has promoted a comprehensive and equitable education service such as the Border Patrol Police School under the Border Patrol Police Headquarters, Royal Thai Police Area of responsibility of the Border Patrol Police Division 13, Sahachristian School Under the Office of the Private Education Commission Etc. However, education in the area is different. Number of students budget and education administration is not 
conducive to effective education management, and the education management has many departments to promote and support education management continuously in order to hope that the quality of education management can be continually developed and to raise the development level, and the Orphanage for Poor Children, CCF, under the Royal Patronage of Her Royal Highness Princess Maha Chakri Sirindhorn Siamboromrajakumari. It is one of the units that continuously promotes and supports education management in the Sangkhlaburi district and from the past management of education, the school has organized learning according to the context and has a network of interaction in some areas, the activities of driving the network to promote learning management are not yet concrete and the lack of mentors to promote learning management and organize activities for the school on an ongoing basis and can be properly integrated with the development of the teaching profession and there is a need to develop a network for promoting education in order to strengthen and be able to develop learners for effective results. From the preliminary problems, the approaches to solving the spatial problems were consistent with the research of Mariam Nilphan and other (2020) [2] presented a paradigm development model mechanism for teacher development based on the spatial network concept. Policy recommendations were made that teacher development should adapt the landscape process to meet the needs of the teachers developers focusing on the spatial effect on the learners, meet the needs of individual teachers apply information technology and build a network of cooperation in the area that related with the research of Sivakorn Rattichote (2018) [3], it can be concluded that running a professional learning community network enables teachers to work as a systematic team and have a continuous learning management mechanism, and improve corporate culture to facilitate contextual learning management, promote collaboration and base building knowledge in developing learners to develop, including the process of conducting classroom research along with teaching and learning to be beneficial and worthwhile. In addition, building a network of professional learning communities will help teachers to consolidate, develop innovative learning, and be able to leverage academics, creating good professional morale. For this reason, the researcher has carefully selected and developed a network for promoting classroom learning management by applying the King's Philosophy together with the professional learning community. It is a method that helps schools to perform effective learning management tasks.

\section{Research Objectives}

The purposes of this research article were 1) to study the background of the school and the need of the network development of classroom learning promotion network of schools in Kanchanaburi Province, 2) to develop the model of classroom learning promotion network of schools in Kanchanaburi Province applying the King's Philosophy with the professional learning community, 3) to study result of utilization model of classroom learning promotion network of schools in Kanchanaburi Province applying the King's Philosophy with the professional learning community, and 4) to evaluate and conduct the lessons learned model of classroom learning promotion network of schools in Kanchanaburi Province applying the King's Philosophy with the professional learning community.

\section{Research Methods}

\section{A. Research Design}

Research design with research and development with Participatory Action Research (PAR) combines both quantitative and qualitative methods (Mixed Methods Research) by conducting 4 steps 1) Research, study needs and approaches network development, 2) Development, build a network development model with the concept of a professional learning community together with the application of the King's Philosophy, 3) Research, the use of the model spatial, 4) Development, synthesis and network expansion.

\section{B. Research Process}

This research is designed by research and development with Participatory Action Research (PAR) combines both quantitative and qualitative methods (Mixed Methods research), and a 4-step research process, as shown in Fig.1.

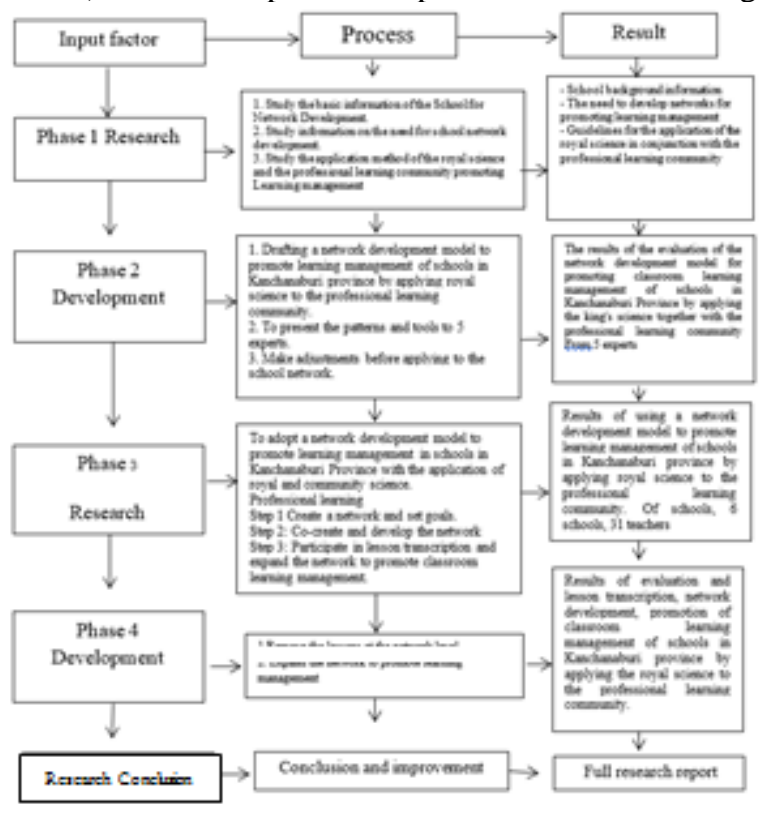

Fig. 1 Research Framework

\section{Results}

1) The results of the study of basic school information and the need to develop a network to promote classroom learning management in schools in Kanchanaburi Province. The study of documents (Document Research and Flied Research) found that the school needs to develop a learning network and promote education management. All sectors saw the importance and agreed .It should be developed to be effective by creating a learning network to promote education management with the concept of applying royal science. A professional learning community and a 
systematic concept was to develop a network to promote learning management for both teachers and learners.

2) Results of education and development of network development to promote learning management in the classrooms of schools in Kanchanaburi Province with the application of royal science in conjunction with the professional learning community, it was found that the expert assessment results had an average score. The overall development has good quality $(\overline{\mathrm{X}}=3.82, \mathrm{SD}=0.67)$ with details of the steps as follows: Step 1 creating network and setting the goal together that consisted of 1.1 Creating school network and make the collaboration (MOU), 1.2 Setting the target for learning promotion, 1.3 Setting plan for network development. Step 2 collaborative creation and network development that consisted of 2.1 Setting group and the target for learning development, 2.2 Problem analysis and create guideline for learning development, 2.3 Setting innovative framework and learning development plan, 2.4 Design and develop learning innovation, 2.5 Supervise and follow up classroom learning development, 2.6 Summarize and conduct lessons learn of learner's development in school. Step 3 Conduct lessons learned and extend learning network that consisted of 3.1 Conduct lessons learned at network level, and 3.2 Extend classroom learning promotion network as shown in Fig.2.

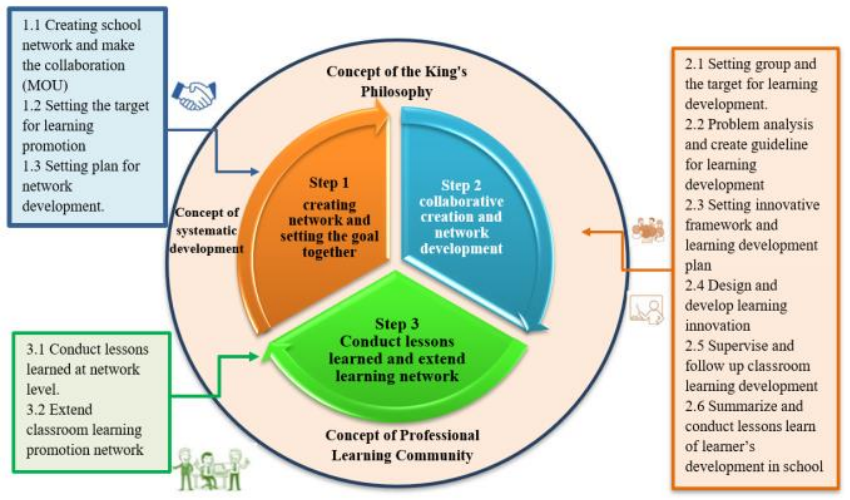

Fig.2 Model development of classroom learning promotion network

3) The results of applying a network development model to promote classroom learning management of Schools in Kanchanaburi Province by applying the royal science together with the professional learning community, it was found that the school director, teachers, students of the CCF Foundation have cooperated in promoting classroom learning and all sectors. Promote learning management to produce spatial outcomes that are appropriate in context and from supervision and monitoring of educational management and classroom learning management of the network schools found that the network school able to perform the work according to the process with the overall average of 92.59 percent.

4) Results of evaluation and lesson transcription, results of using a network development model to promote learning management Schools in Kanchanaburi Province by applying the royal science together with the professional learning community 1) Results of the use of networks to promote learning management in overall teachers had a good level of post-development knowledge $(\bar{X}=4.30$, S.D. $=0.57)$ than before development, knowledge was at a moderate level
$(\bar{X}=2.60, S D=0.64) 2)$, teacher's self-improvement results after development had a good level of knowledge $(\bar{X}=4.35$, $\mathrm{SD}=0.57)$ than before the development of knowledge at the moderate level $(\bar{X}=2.63, \mathrm{SD}=0.76), 3)$ the results of learning development in learning management in Postdevelopment teacher classes were at a good level $(\bar{X}=4.37$, S.D. $=0.58)$, higher than before development at a moderate level $(\bar{X}=2.49$, S.D. $=0.83)$, and 4) outcomes for postlearner development behavior and knowledge at a high level $(\bar{x}=3.91$, S.D. $=0.63)$ than before participating in the project, the learners had moderate behavior and knowledge $(\bar{X}=2.49$, S.D. $=0.83)$.

\section{Discussions}

1) Results of the study of basic school information and needs to develop a network to promote school learning management in Kanchanaburi Province from document research and flied research, it was found that the school needed to build a learning network to promote education management and that is important, all parts have a consensus should develop to be effective by applying the principles of networking, emphasizing participation, promoting education management based on the concept of applying the King's Philosophy, using the professional learning community, working towards developing results, promoting learning management for both teachers and students. There is a network operation concept to promote classroom learning management and choose an idea applications of the King's Philosophy for participation in network development. This is because the schools in the area are border areas of Kanchanaburi Province, operations in such areas are various service areas, slow access by distance. Running a cooperative network is one strategy that allows schools to operate in the area. This comes from the need for development work in the area. It is important that all parties have the same goals and priorities and the consideration of management with an agency that is a coordinator in this research, the CCF Foundation is the starting point for coordinating the development of education management in the area so that the dimension of education management can be developed for sustainability spatial operations are driven by the problems of the area. It is consistent with Sergiovanni (1984) [4] that action stems from the leadership of the academy administrators with a shared vision according to technical leadership principles Human leadership Educational leadership Symbolic leadership and cultural leaders, and implemented integrated management, applied to suit the area also Mariam Nilphan and others (2020) [5] has found that teacher development should adjust the visualization process in accordance with the needs of the development recipient, focusing on the spatial effect of the learners, responding to the individual teachers' needs, applying information technology, and building network of local cooperation

2) Results of education and development of network development to promote learning management Schools in Kanchanaburi Province by applying the royal science in conjunction with the professional learning community, it was found that the results of expert evaluation conducted an overall expert evaluation of the network model. Developed with good quality $(\bar{x}=3.82$, S.D. $=0.67)$. This is because 
the researcher has studied the document concepts, theories, and synthesizes the process until it gets the steps that are suitable for the area. In addition, the study of needs and possibilities in the area to be appropriate according to the concept of the King's Philosophy that the researcher has considered using the work principles to apply to the concept of the professional learning community. It is a thought-topractice principle that helps make each stage of the professional learning community more prominent. The implementation of each step of the network development has also integrated the concept of royalism as a development step in driving the network. Results for all parties starting from the school started a broader administrative development in management that is not solely driven by management. As for the teachers, they develop innovative learning for learners and develop themselves in their profession. Moreover, learners are continually developed and supported both internally and externally from cooperation in promoting educational management. These are the ways in which a stronger network is built by joining hands with the heads of departments who have to formulate common guidelines to drive the network to success consistent with the concept of the Office of the National Economic and Social Development Board (2011) [6], the Office of the National Economic and Social Development Board (2008) [7] and the Office of the National Economic and Social Development Board. Foundation of the Research and Development Institute of Thailand according to the Philosophy of Sufficiency Economy, the Crown Property Bureau, a project to support the self-sufficiency economy in education and youth, provides information that the science of the monarchy is the science of application in daily life and normal work. If applied continuously, it will bless the life of the leader. It is also in line with the ideas of Dufour, R., Dufour, R., \& Eaker, R. (2008) [8], who say that building a professional learning community is an art of collaborative learning, join to create the power of learning, participate in developing learners to become a professional learning community. That all parties join together to support and share together until strength in the area of education management and a sustainable organizational change and Wawrathamongkol (2018) [9] also mentioned that the professional learning community will help foster professional advancement through mutual learning like Kalyanamit.

3) The results of implementing a network development model to promote school learning management Kanchanaburi Province, with the application of the royal science in conjunction with the professional learning community, it was found that all departments of the school, including the school director, teachers, students of the CCF Foundation, have cooperated in promoting classroom learning management by implementing a 3-step sequence, step 1, creating a network and setting goals together, Step 2, co-creating and developing a network, Step 3, joining lessons and expanding the learning network from the said operation. Sequential processes are formed and spatial results are achieved and can be applied to appropriate process results. This is because conducting classroom learning management activities for teachers participating in the project Sangkhlaburi District Kanchanaburi. Teachers who participated in the project followed the follow-up plan and the teachers in the project were able to apply the knowledge from the training and apply it to their own classes effectively by observing the use of hierarchical teaching materials, learning activities getting learners to take action, activities and classroom management. The project teachers had an exchange of knowledge in the media, organizing learning and self-development as well as exchanging attitudes in teaching professional practice from various sub-jurisdictions to become a strong learning network in teaching and learning development in Sangkhlaburi district, Kanchanaburi. In addition, there is a capacity building for learning activities and using media in learning management for teachers in Sangkhlaburi District, Kanchanaburi. Teachers participating in the project can apply their knowledge to organizing learning activities. Conforms to the Wohlstetter (1995) [10]: Odden and Wohlstetter (1995) [11] principle that school-based operations are based on three main principles: decentralization, participation, and reinstatement of education people on principles of self-management and principles of checks and balances.

4) Results of evaluation and lesson transcription, network development model promoting learning management Schools in Kanchanaburi Province by applying the royal science in conjunction with the professional learning community showed that 4.1) Results of using the network to promote learning management by applying the royal science in conjunction with the professional learning community teachers have different knowledge before the development the knowledge was at a moderate level $(\bar{X}=2.60$, S.D. $=$ $0.64)$, after the development was at a good level $(\bar{X}=4.30$, S.D. $=0.57)$. 4.2) The results of the study mean predevelopment and post-development teacher development scores were different. The knowledge behavior was at a moderate level $(\bar{X}=2.63$, S.D. $=0.76)$, and after the development, the cognitive behavior was at a good level $(\bar{X}=4.35$, S.D. $=0.57)$ in several indicators. The teachers who participated in the project had also improved at a good level. 4.3) Learning development results, teachers' classroom learning management, results of the study showed that the overall mean scores before development and post development were at different levels, with pre-development at a moderate level $(\overline{\mathrm{X}}=2.49, \mathrm{SD}=0.83)$ and postdevelopment at a good level $(\bar{X}=4.37, \mathrm{SD}=0.58)$. 4.4) Student development results Before participating in the project, the learners had a moderate level of behavior and knowledge, and after the development, learners have behavior and knowledge at a high level $(\overline{\mathrm{x}}=2.49$, S.D. $=$ $0.83)$. The results arising from the learning behaviors that teachers have organized activities for students are responsive with smiles, joy, fun friendship and human relations with classmates. Teachers of all schools deliver results using media and innovation has achieved goals, and the results of the lesson transcription. The results of building a professional learning community network, teacher development results of teaching and learning development showed that student development from both the quantitative and qualitative study data, teachers in the Sangkhlaburi district have more activities to exchange and learn in accordance with the steps taken from the training, which previously had little activity in spatial nature. If it was a school-based activity in other matters, taking part in this 
activity is a good opportunity for teachers of many affiliations to meet and chat. Participate in learning exchange activities was to develop spatial learners and the learning network under the affiliate exchanged ideas for the development of students in the classroom exchange of classroom activities, exchange of ideas, media development, learning activities, exchange of classroom experiences. The exchange of spirituality among teachers between graduating teachers and non-graduating teachers by participating in this project, teachers can develop more learner-centered learning management skills and see the importance of organizing learning activities for improving learners' learning in the classroom more and more. Learning activities are increasingly adapting traditional learning activities to integrate with media and technology in some schools that are ready and conducive to using technology for developing learners to be more interactive during their classroom learning. It is a good thing to develop all teachers have learned new things. There are techniques for organizing knowledge-enhancing activities from two award-winning teachers of Prince Maha Chakri that help nurture inspiration in organizing learning activities to create simple media based on the context around them. Strategies for organizing a successful learning activity were used for participation in learner development that helps achieve learning goals, techniques and skills for teaching and learning activities. The development of innovative teaching and learning management were applied on literacy for students as a demand-based innovation that the area has developed from the goals of network development from the management to promote innovation in organizing spatial learning activities. Teachers can analyze student problems, and create innovative materials that are easy to learn for the spatial learners. The innovation is developed in accordance with the kindergarten level until secondary school year 3, focusing on the knowledge of the Thai language as a base and integration with other subjects. As a result of this, it has resulted in organizational results, a transformation towards success, and holistic learning in line with the concept of the Office of the National Economic and Social Development Board (2011) [12] Thira Rooncharoen (2007) [13] and (David, 1989 cited in Cheng, 1996: 4) [14]. It is the base and application of the king's science, which emphasizes the participation and decision making of the administrators and teachers as well as the school committee to plan and decide on actions to suit the area. It also forwarded the learning atmosphere of the learners and the operation of all parts of the work, all parts can be operated according to the principle of school administration as a base, namely 1) the school is an agency that can create a network and make decisions in the performance of every department in School and work development to be more strengthened without hesitation, centralized drive, and 2) participatory actions, sharing opinions, joining the educational management reforms from members of the participating areas, and it was born from the community to cooperate and make decisions in the administration and to achieve concrete results.

\section{Recommendations}

In conducting the research, recommendations from the next development work are as follows:
1. For the implementation of cooperation, the details of the activities and processes should be explained to educational institutions and organizations in order to carry out the work development activities in a reasonable time and include details of administrative management on budgeting.

2. A voluntary survey and the readiness of the school should be conducted in the process of developing teachers and include the identification of the person responsible for coordinating the project on the part of the school and the departments that are being developed and must know the development goals and methods. The steps are the same throughout, including goals and follow-up details.

3. Implementation of roles of participation, management and development networks should receive management innovation in addition to teaching and learning media innovation since the administrators will have to monitor with processes and have directions for learner development according to the local context.

4. The project duration should have an educational management plan of marginal schools or border schools with both short-term and long-term plans in line with changing and developing learners to be on par with other countries.

5. To promote the management of spatial education, there are many aspects that should promote the management process and details of the operations, the activities must be presented to the high management in the area and all areas for acknowledgment and jointly drive them to be more concrete.

\section{Conclusion}

Applications of the King's Philosophy in the professional learning community and the systematic thinking to develop classroom learning promotion network. There are network implementation steps as follows: step 1 is to build the network and set the target, step 2 is to cooperate creative network development, and step 3 is to conduct lessons learned and extend learning network. Operations must be cooperation as the core and all parties recognize and appreciate the performance. Responsibility in the work and respect and coherence in driving a network is one of the keys to a successful network development, and the development of teachers and learners must come from meetings and share their thoughts explosive from the heart, and study step by step increasing the quality of education will develop even more, affecting the overall educational development of the country.

\section{References}

[1] Office of the Education Council Secretariat, Guidelines for the development of Thai education and preparation for the 21st century, Bangkok: Prik Wan Graphic, 2014.

[2] [2][5] M. Nilpan, et al., Paradigm development of teacher development mechanism model based on spatial 
network concept: a case study of central region. Including the East and the West with a model policy suggestion, Mechanism for teacher development based on the concept of the central geospatial network Including Eastern and Western regions, Journal of Curriculum Research and Development, Vol.10, Issue 1, (January - June 2020): 226-243.

[3] [3] S. Ratichote, Guidelines for the development of professional learning communities for classroom research of teachers in secondary schools, Bangkok, Office of the Basic Education Commission: Combined Research Methodology, Ph.D. in Human Potential Research and Development, Srinakharinwirot University, 2018.

[4] [4] T.J. Sergiovanni, Seven Steps to Effective Instructional Leadership, New York: McGraw-Hill, 1984.

[5] [6] Office of the National Economic and Social Development Board, National Development Work of His Majesty, Bangkok: Petch Rung Printing Center, 2011.

[6] [7] Office of the National Economic and Social Development Board. Learn about the work principles in His Majesty, Bangkok: 21 Century Company Limited, 2008.

[7] [8] R. Dufour, R. Dufour, \& R. Eaker, Revisiting professional learning communities at work: New insights for improving schools. Bloomington, IL: Solution Tree Press, 2008.

[8] [9] K. Wiwatmongkol, Model of developing teachers by using the process of Professional Learning Community (PLC) in promoting learning management abilities based on the STEM education approach at the basic education level, Veridian E- Journal, Silpakorn University, Vol.11, issue 3, September - December 2018: 92-114.

[9] [10] P. Wohlstetter, Getting School-based Management Right: What Works and
What Doesn, Phi Delta Kappan, 77 (1), (1995, September): 22-25.

[10] [11] E.R. Odden, and Wohlstetter, "Marking School - Based Management Work," Educational Leadership, 54 (7): 1995: 2425 - A.

[11] [12] Office of the National Economic and Social Development Board, National Development Work ofHis Majesty, Bangkok: Petch Rung Printing Center, 2011.

[12] [13] Teerarooncharoen, Professionalism in educational organization and administration in the education reform era, 4th edition, Bangkok: L.T. Press, 2007.

[13] [14] Y. C. Cheng, School effectiveness and school-based improvement: A mechanism for development, London: Falmer Press, 1996a 